\title{
MODEL EKSPERIMENTAL LIMPASAN PERMUKAAN PADA PERKERASAN PAVING BLOCK DENGAN PENAMBAHAN RUMPUT ANTAR PAVING
}

\author{
I Wayan Yasa ${ }^{1)}$, I D.G. Jaya Negara1), I B. Giri Putra'), dan Ni Kadek Asri R. W.1)
}

1) Jurusan Teknik Sipil, Fakultas Teknik, Universitas Mataram, Nusa Tenggara Barat

yasaiwayan68@unram.ac.id

\begin{abstract}
The use of pavement is increasing as an impact of urban development. The pavement of the land surface is very influential on increasing surface runoff. The surface runoff will cause flooding and inundation if the drainage system is not good. The use of pavement that can reduce runoff is needed, to reduce the occurrence of floods. This study aims to determine the effect of the land surface on the value of the surface runoff coefficient $(C)$. The material used is in the form of paving blocks with the fill of grass between paving blocks. This research was conducted using a rainfall simulator. The material used is brickshaped paving blocks of size $20 \times 10 \times 8 \mathrm{~cm}$ with a variety of brick stacking patterns and woven mats combined with mini elephant grass with a mix ratio of $75 \%: 25 \%$. The measurement results are rainfall intensity, runoff volume, and surface runoff coefficient $(C)$. The results showed that the addition of mini elephant grass had an influence on the value of the runoff coefficient. In paving blocks without the fill of mini elephant grass has a greater coefficient. The runoff coefficients produced include: soil runoff coefficient values ranging from 0.39 - 0.44, paving blocks for brick stacking runoff coefficients range from 0.42 - 0.46, paving blocks woven mat ranges from 0.41 - 0.45, paving blocks brick stacking patterns with the fill of mini elephant grass runoff coefficient ranging from 0.40 to 0.45 , and paving block woven mat patterns with of mini elephant grass runoff coefficient ranging from $0.36-0.41$.
\end{abstract}

Keywords: rainfall, paving blocks, runoff, grass 


\begin{abstract}
ABSTRAK
Pemanfaat perkerasan semakin meningkat sebagai dampak dari berkembangnya perkotaan. Perkerasan permukaan lahan sangat berpengaruh pada meningkatnya limpasan permukaan. Limpasan permukaan yang terjadi akan mengakibatkan terjadinya banjir dan genangan jika sistem drainasenya tidak baik. Penggunaan perkerasan yang mampu mengurangi limpasan sangat diperluka, untuk mengurangi terjadinya banjir. Penelitian ini bertujuan untuk mengetahui pengaruh permukaan lahan terhadap nilai koefisien limpasan permukaan (C). Material permukaan yang digunakan yaitu berupa paving block dengan penambahan rumput antar paving block. Penelitian ini dilakukan dengan menggunakan alat rainfall simulator. Penelitian ini menggunakan paving block berbentuk bata ukuran $20 \times 10 \times 8 \mathrm{~cm}$ dengan variasi pola pemasangan susun bata dan anyaman tikar yang dikombinasikan dengan rumput gajah mini dengan perbandingan campuran 75\%:25\%. Pengukuran yang dilakukan yaitu pengukuran intensitas hujan, volume limpasan, dan koefisien limpasan permukaan $(C)$. Hasil penelitian menunjukkan bahwa penambahan rumput gajah mini memberikan pengaruh terhadap nilai koefisien limpasan permukaan. Pada paving block tanpa penambahn rumput gajah mini memiliki nilai koefisien yang lebih besar. Koefisien limpasan yang dihasilkan diantaranya : tanah nilai koefisien limpasannya yaitu berkisar 0.39 - 0.44, paving block susun bata koefisien limpasannya berkisar 0.42 - 0.46, paving block anyam tikar berkisar 0.41-0.45, paving block pola susun bata dengan penambahan rumput gajah mini koefisien limpasan berkisar 0.40 - 0.45, dan paving block pola anyaman tikar dengan penambahan rumput gajah mini koefisien limpasan berkisar 0.36 - 0.41.
\end{abstract}

Kata kunci: hujan, paving block, limpasan, rumput 


\section{PENDAHULUAN}

\subsection{Latar Belakang}

Pembangunan di daerah perkotaan yang semakin berkembang sebagai dampak dari pertumbuhan penduduk, pertumbuhan ekonomi, dan perkembangan pariwisata yang pesat, menyebabkan berkurangnya lahan hijau untuk resapan air hujan ke dalam tanah, sehingga debit limpasan permukaan (surface run off) meningkat yang dapat memicu banjir dan genangan air. Untuk mengurangi terjadinya banjir dan genangan, maka perlu upaya untuk mengurangi penggunaan tutupan lahan kedap air (perkerasan beton) dan menggantinya dengan tutupan lahan yang dapat meningkatkan resapan air hujan.

Salah satu solusi yang dapat dilakukan untuk mangatasi masalah genangan tersebut yaitu dengan cara mempercepat resapan air hujan ke dalam tanah, membuka pori pada lahan-lahan yang telah di beton dengan cara mengganti dengan tutupan lahan yang tembus air (permeable pavement), sehingga dapat mengurangi aliran permukaan.

Jenis perkerasan tembus air yang banyak digunakan adalah paving block. Paving block telah dikenal luas sebagai teknologi alternatif untuk mengurangi volume limpasan dan memperkecil nilai koefisien limpasan karena kinerja infiltrasi dan kemampuan memperlambat aliran. Kontruksi perkerasan dengan paving block merupakan kontruksi yang ramah lingkungan dimana paving block sangat baik dalam membantu konservasi air tanah, pelaksanaannya yang lebih cepat, mudah dalam pemasangan dan pemeliharaan, memiliki aneka ragam bentuk yang menambah nilai estetika, serta harganya yang cukup terjangkau.

Setiap jenis paving block memiliki kinerja yang berbeda dalam mengurangi limpasan permukaan. Area bukaan antar paving block merupakan peran penting dalam mengurangi limpasan permukaan. Untuk meningkatkan kinerja paving block dalam mengurangi limpasan permukaan dan meningkatkan laju infiltrasi pada penelitian ini dilakukan variasi pola pemasangan paving block dimana pada area bukaan paving block akan ditanami rumput. Berdasarkan uraian diatas, maka akan dilakukan penelitian pengaruh penambahan rumput dan variasi pola pemasangan paving block terhadap limpasan permukaan. Hasil penelitian ini diharapkan dapat menunjukkan jenis tutupan lahan berwawasan lingkungan yang memiliki kemampuan terbesar dalam mengurangi debit aliran permukaan. 


\subsection{Rumusan Masalah}

1. Berapa volume limpasan permukaan pada paving block dengan penambahan rumput pada sela-sela paving block.

2. Berapa koefisien limpasan permukaan pada paving block dengan penambahan rumput pada sela-sela paving block.

3. Bagaimana pengaruh paving block terhadap limpasan permukaan dengan penambahan rumput pada sela-sela paving block.

\subsection{Tujuan}

1. Mendapatkan volume limpasan permukaan pada paving block dengan penambahan rumput pada sela-sela paving block.

2. Mendapatkan nilai koefisien limpasan pada paving block dengan penambahan rumput pada sela-sela paving block.

3. Mendapatkan pengaruh paving block terhadap limpasan permukaan dengan penambahan rumput pada sela paving block.

\subsection{Batasan Penelitian}

1. Kedalaman hujan dimodelkan seragam.
2. Lapisan tanah dasar diperlakukan sudah pada kondisi jenuh.

3. Mengabaikan kualitas atau kekuatan dari paving block.

\section{KAJIAN PUSTAKA}

\subsection{Limpasan Permukaan}

Limpasan permukaan (surface runoff) adalah bagian dari curah hujan yang mengalir di atas permukaan tanah menuju ke sungai, danau, dan lautan. Limpasan permukaan terjadi ketika kapasitas infiltrasi tanah tidak dapat menyeimbangkan intensitas curah hujan di permukaan tanah. Pada umumnya limpasan permukaan tidak terjadi segera setelah hujan jatuh di permukaan tanah, tetapi perlu waktu untuk memenuhi kapasitas infiltrasi. Kapasitas infiltrasi adalah kemampuan tanah dalam menyerap (menginfiltrasikan) air yang terdapat di permukaan atau aliran air permukaan tanah. Semakin besar kapasitas infiltrasi maka aliran air di permukaan tanah makin berkurang. Laju infiltrasi dan kapasitas infiltrasi di pengaruhi oleh tekstur tanah, struktur tanah, tipe vegetasi, tata guna lahan, suhu tanah dan intensitas hujan.

\subsection{Intensitas Hujan}

Intensitas hujan adalah banyaknya curah hujan pada jangka waktu tertentu. 
Intensitas hujan menunjukkan tingginya curah hujan persatuan waktu, yang dinyatakan dalam $\mathrm{mm} / \mathrm{menit}, \mathrm{mm} / \mathrm{jam}$ atau $\mathrm{mm} /$ hari. Jumlah hujan akan menunjukkan banyaknya air hujan selama terjadi hujan dalam kurun waktu tertentu. Pengaruh intensitas hujan terhadap limpasan permukaan sangat tergantung pada laju infiltrasi. Jika intensitas hujan melebihi laju infiltrasi, maka akan terjadi limpasan pemukaan. Berikut klasifikasi intensitas hujan yang disajikan dalam Tabel 1 .

\section{Tabel 1. Klasifikasi Intensitas Hujan}

\begin{tabular}{ccc}
\hline No & $\begin{array}{c}\text { Intensitas Hujan } \\
(\mathrm{mm} / \mathrm{jam})\end{array}$ & Klasifikasi \\
\hline 1 & $0-5$ & Sangat kecil \\
2 & $6-10$ & Kecil \\
3 & $11-25$ & Sedang \\
4 & $26-50$ & Agak Besar \\
5 & $51-75$ & Besar \\
6 & $>75$ & Sangat Besar \\
\hline
\end{tabular}

Sumber: Martono, 2004

Intensitas hujan yang didapat pada alat ukur curah hujan dapat diperoleh dengan persamaan berikut ini:

$$
\begin{aligned}
& I=\frac{\mathrm{d}}{\mathrm{t}} \\
& \mathrm{d}=\frac{\mathrm{V}}{\mathrm{A}}
\end{aligned}
$$

dengan:

$$
\begin{aligned}
\mathrm{I}= & \text { intensitas hujan }(\mathrm{mm} / \mathrm{jam}) \\
\mathrm{d}= & \text { tinggi hujan }(\mathrm{mm}) \\
\mathrm{t}= & \text { waktu }(\mathrm{jam}) \\
\mathrm{V}= & \text { volume air yang tertampung } \\
& \left(\mathrm{mm}^{3}\right)
\end{aligned}
$$

$$
\begin{aligned}
A= & \text { luas penampang alat curah } \\
& \text { hujan }\left(\mathrm{mm}^{2}\right)
\end{aligned}
$$

\subsection{Koefisien Aliran Permukaan (C)}

Koefisien aliran permukaan (C) didefinisikan sebagai nisbah antara laju puncak aliran permukaan terhadap intensitas hujan. Faktor utama yang mempengaruhi nilai $\mathrm{C}$ adalah laju infiltrasi tanah, tanaman penutup tanah dan intensitas hujan (Arsyad, 2006). Faktor utama yang mempengaruhi nilai $\mathrm{C}$ adalah laju infiltrasi tanah atau persentase lahan kedap air, kemiringan lahan, tanaman penutupan tanah dan intensitas hujan. Koefisien limpasan juga tergantung pada sifat dan kondisi tanah. Faktor lain yang mempengaruhi nilai koefisien limpasan adalah air tanah, derajat kepadatan tanah, dan porositas tanah (Suripin, 2004).

Adapun nilai koefisien aliran permukaan (C) dari definisi diatas dapat diterjemahkan dalam rumus rasional sebagai berikut (Akara et al., 2016):

$$
\mathrm{C}=\frac{\mathrm{Q}}{\mathrm{I} \times \mathrm{A}}
$$

dengan:

$$
\begin{aligned}
\mathrm{Q}= & \text { debit aliran permukaan } \\
& \left(\mathrm{mm}^{3} / \mathrm{jam}\right) \\
\mathrm{I}= & \text { intensitas hujan }(\mathrm{mm} / \mathrm{jam}) \\
\mathrm{A}= & \text { luas area uji }\left(\mathrm{mm}^{2}\right) \\
\mathrm{C}= & \text { koefisien pengaliran }
\end{aligned}
$$


Koefisien aliran permukaan (C) merupakan salah satu komponen hidrologi yang berpengaruh terhadap daerah aliran sungai (DAS). Nilai C yang kecil menunjukkan suatu DAS masih dalam kondisi yang baik, sebaliknya nilai $\mathrm{C}$ yang besar menunjukkan DAS yang sudah rusak. Nilai $\mathrm{C}$ dikatakan besar apabila $\mathrm{C}=$ 1 (Suripin, 2004).

\subsection{Paving block}

Paving block merupakan produk bahan bangunan yang digunakan sebagai alternatif pengerasan permukaan jalan yang dibuat dari campuran semen, air dan agregat dengan atau tanpa campuran bahan lainnya yang tidak mengurangi mutu bata beton tersebut (Sebayang, et al., 2011). Paving block sendiri mempunyai beberapa variasi bentuk untuk memenuhi kebutuhan, misalnya saja digunakan sebagai tempat parkir, terminal, jalan setapak, untuk halaman restoran atau perkantoran, jalan pada taman, dan juga perkerasan jalan di kompleks-kompleks perumahan serta keperluan lainnya.

Warna paving block yang tersedia di pasaran antara lain abu-abu, merah dan hitam (Artiyani, 2010). Dalam pemasangan paving block memiliki banyak variasi dalam pemasangannya. Pola pemasangan paving block yang umum digunakan adalah susun bata (stretcher), anyaman tikar (basket weave) dan tulang ikan (herringbone).

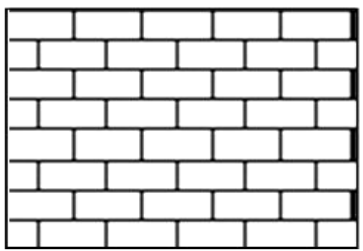

a. Pola susun bata

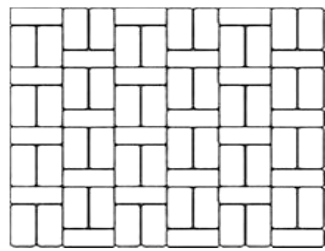

b. Pola anyam tikar
Gambar 1 Pola Pemasangan Paving Block (Sumber: Sedyowati dan Susanti, 2017)

Pada penelitian ini digunakan paving block berbentuk bata dengan variasi pola pemasangan susun bata (stretcher), dan anyaman tikar (basket weave).

\subsection{Rumput}

Rumput (grass) adalah tumbuhan monokotil yang memiliki daun berbentuk sempit meruncing yang tumbuh dari dasar batang. Rumput seringkali ditanam sebagai tanaman hias, tanaman obat, dan pakan ternak. Namun di sisi lain, rumput yang tumbuh di lahan pertanian bersifat mengganggu pertumbuhan tanaman utama sehingga sering disebut sebagai tanaman pengganggu (gulma) (Akara et al., 2016).

Rumput dapat dibedakan menjadi beberapa jenis yaitu rumput peking, rumput gajah, rumput golf dan rumput jepang. Rumput peking memiliki karakteristik daun yang kurus, rumput peking memiliki kecenderungan untuk menguning bila tidak terpapar sinar 
matahari. Rumput jepang memiliki karakteristik daun yang lurus dan rapat, namun pertumbuhannya termasuk lambat sehingga tidak cepat lebat. Rumput golf memiliki tekstur bergelombang dan sangat lembut. Rumput gajah termasuk jenis rumput paling kuat dalam menahan tekanan dan tahan pada berbagai kondisi tanah, memiliki karakteristik daun yang cukup besar dan kasar. Salah satu jenis rumput gajah yang baru dikembangkan adalah rumput gajah mini (Pennisetum purpureum schamach).

\subsection{Tanah}

Laju infiltrasi dan kapasitas infiltrasi di pengaruhi oleh tekstur tanah, struktur tanah, tipe vegetasi, tata guna lahan, suhu tanah dan intensitas hujan. Selain itu laju infiltrasi sangat bergantung pada karakteristik tanah dan air. Biasanya kondisi tanah yang jenuh air (tanah dengan kadar air yang tinggi) menunjukkan laju infiltrasi yang lebih rendah dibandingkan tanah yang tidak jenuh air (Harisuseno et al., 2017).

Tekstur tanah, biasa juga disebut besar butir tanah. Tekstur tanah adalah keadaan tingkat kehalusan tanah yang terjadi karena terdapat perbedaan komposisi kandungan fraksi pasir (sand = diameter $2-0.22 \mathrm{~mm}$ ), debu (silt $=$ diameter $0.2-0.002 \mathrm{~mm}$ ) dan liat (clay $=$ diameter lebih kecil dari $0.002 \mathrm{~mm}$ ), partikel berukuran diatas $2 \mathrm{~mm}$ seperti kerikil dan batuan kecil tidak digolongkan sebagai fraksi tanah. Tanah dengan berbagai perbandingan pasir, debu dan liat dikelompokkan atas berbagai kelas tekstur seperti digambarkan pada segitiga tekstur.

\section{METODE PENELITIAN}

\subsection{Rancangan Penelitian}

Pelaksanaan penelitian dilaksanakan di Laboratorium Hidrolika dan Pantai dan Laboratorium Geoteknik Fakultas Teknik Universitas Mataram.

\subsection{Alat dan Bahan}

\subsubsection{Rainfall simulator}

Alat rainfall simulator (Gambar 2) digunakan untuk mengetahui intensitas hujan buatan. Uji coba dilakukan dengan mengalirkan hujan dengan interval waktu 10 menit, 20 menit, 30 menit 40 menit dan 60 menit. Luas lahan uji $200 \mathrm{~cm}$ x $100 \mathrm{~cm}$. Meletakkan alat ukur hujan pada lahan uji. Air hujan yang tertampung kemudian di ukur volumenya untuk mengetahui intensitas hujan.

\subsubsection{Bahan}

1. Paving block yang digunakan berbentuk bata berdimensi 20 $\mathrm{cm}$ x $10 \mathrm{~cm}$ x $8 \mathrm{~cm}$ (Gambar 3). 
2. Tanah yang digunakan adalah tanah disekitar Laboratorium Hidrolika Dan Pantai Jurusan Teknik Sipil Fakultas Teknik Universitas Mataram

3. Rumput yang digunakan dalam penelitian ini yaitu rumput hias gajah mini.

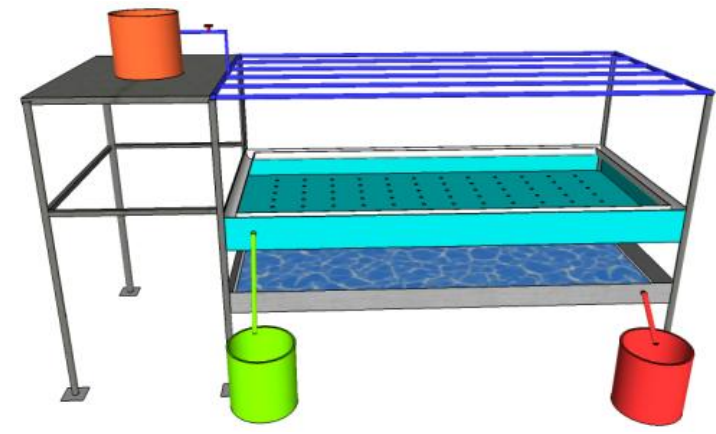

Gambar 2. Rainfall Simulator

(Sumber: Laboratorium Hidrolika dan Pantai Teknik Sipil Unram, 2020)
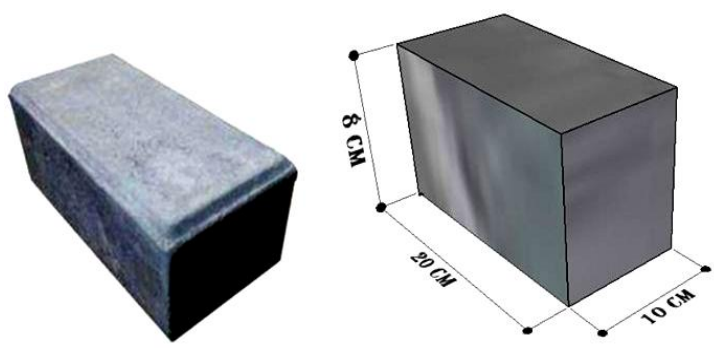

Gambar 3. Paving block dan Dimensi Paving Block

(Sumber: Sedyowati dan Susanti, 2017)

\subsection{Prosedur Penelitian}

Metode yang digunakan dalam penelitian ini adalah metode dengan pengujian laboratorium yang dilakukan di Laboratorium Hidrolika dan Pantai Jurusan Teknik Sipil Fakultas Teknik Universitas Mataram. Sedangkan penelitian ini dilakukan pemodelan menggunakan alat rainfall simulator dengan ukuran bak uji $200 \mathrm{~cm} \times 100 \mathrm{~cm} \times 35 \mathrm{~cm}$. Tutupan lahan rumput yang digunakan pada pengujian adalah jenis gajah mini (Pennisetum purpureum schamach). Pada pengujian ini paving block berdimensi $20 \mathrm{~cm} \times 10 \mathrm{~cm}$ dengan tebal $8 \mathrm{~cm}$. Adapun tahap selanjutnya dengan pembuatan model pengujian sebagai berikut:

1. Memasukkan lapisan dasar tanah pada lahan uji, dan melakukan pengujian.

2. Melakukan pengujian untuk tutupan lahan (paving block pola susun bata, paving block anyam tikar, paving block pola susun bata dengan penambahan rumput, paving block anyam tikar dengan penambahan rumput gajah mini dengan perbandingan $75 \%: 25 \%$,) Gambar 4 dan 5).

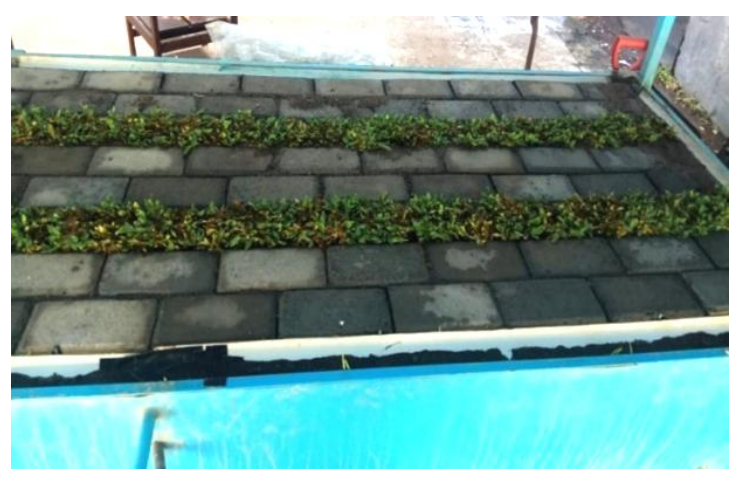

Gambar 4. Pemasangan Paving Block Pola Susun Bata dengan Penambahan Rumput Gajah Mini

(Sumber: Laboratorium Hidrolika dan Pantai Teknik Sipil Unram, 2020) 


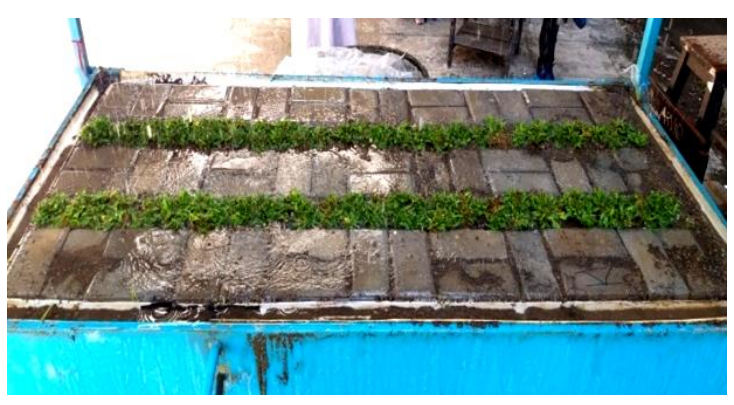

Gambar 5. Pemasangan Paving Block Pola Anyaman Tikar Dengan Penambahan Rumput Gajah Mini

(Sumber: Laboratorium Hidrolika dan Pantau Teknik Sipil Unram, 2020)

Dilakukan pengujian dengan intensitas hujan $300 \mathrm{~mm} / \mathrm{jam}$, dan durasi hujan selama 15, 25, 40, 65, 80 dan 100 menit. Data aliran limpasan permukaan yang tertampung di analisis untuk mendapatkan perhitungan nilai koefisien aliran permukaan (C), selanjutnya dilakukan perbandingan intensitas hujan dan tutupan lahan terhadap nilai koefisien aliran.

\section{HASIL DAN PEMBAHASAN}

\subsection{Jenis Tanah}

Pengujian ini dilakukan untuk mengetahui jenis tanah yang dipergunakan dalam penelitian. Pengujian ini berupa analisis saringan dan hydrometer dilakukan untuk mendapatkan pembagian ukuran butiran yang akan dipergunakan untuk menentukan jenis tanah yang di pergunakan dalam penelitian. Untuk mengetahui jenis tanah pada penelitian digunakan segitiga tektur tanah dengan menggunkan persentase butiran dari hasil analisis saringan dan hydrometer. Hasil analisis uji saringan dan hydrometer dapat dilihat pada Tabel2 dan Gambar 6 .

\section{Tabel 2. Persentase Gradasi Butiran}

\begin{tabular}{cc}
\hline Jenis butiran & $\begin{array}{c}\text { Persentase Gradasi } \\
\text { Butiran }(\%)\end{array}$ \\
\hline Kerikil & 3.8 \\
Pasir & 50.4 \\
Debu & 44.0 \\
Liat & 1.8 \\
\hline
\end{tabular}

Hasil dari ploting segitiga tekstur tanah yang dipergunakan termasuk kedalam jenis tanah lempung berpasir (Gambar 7). Adanya perbedaan sifat fisik tanah akan menentukan kemampuan tanah meresapkan air.

\subsection{Intensitas Hujan}

Pengujian untuk menentukan intensitas hujan dilakukan sebanyak 3 kali kemudian di ambil nilai rata-rata nya. Hal ini dilakukan untuk mendapatkan hasil yang lebih akurat.

Tabel 3. Hasil Pengujian Intensitas Hujan

\begin{tabular}{ccc}
\hline No. & Waktu (Menit) & $\begin{array}{c}\text { Intensitas Hujan } \\
(\mathrm{mm} / \mathrm{jam})\end{array}$ \\
\hline 1 & 15 & 300.71 \\
2 & 25 & 300.96 \\
3 & 40 & 300.87 \\
4 & 65 & 300.04 \\
5 & 80 & 300.87 \\
6 & 100 & 300.49 \\
\hline
\end{tabular}

Dari hasil pengujian intensitas hujan yang dipergunakan yaitu intensitas 300 $\mathrm{mm} / \mathrm{jam}$. 


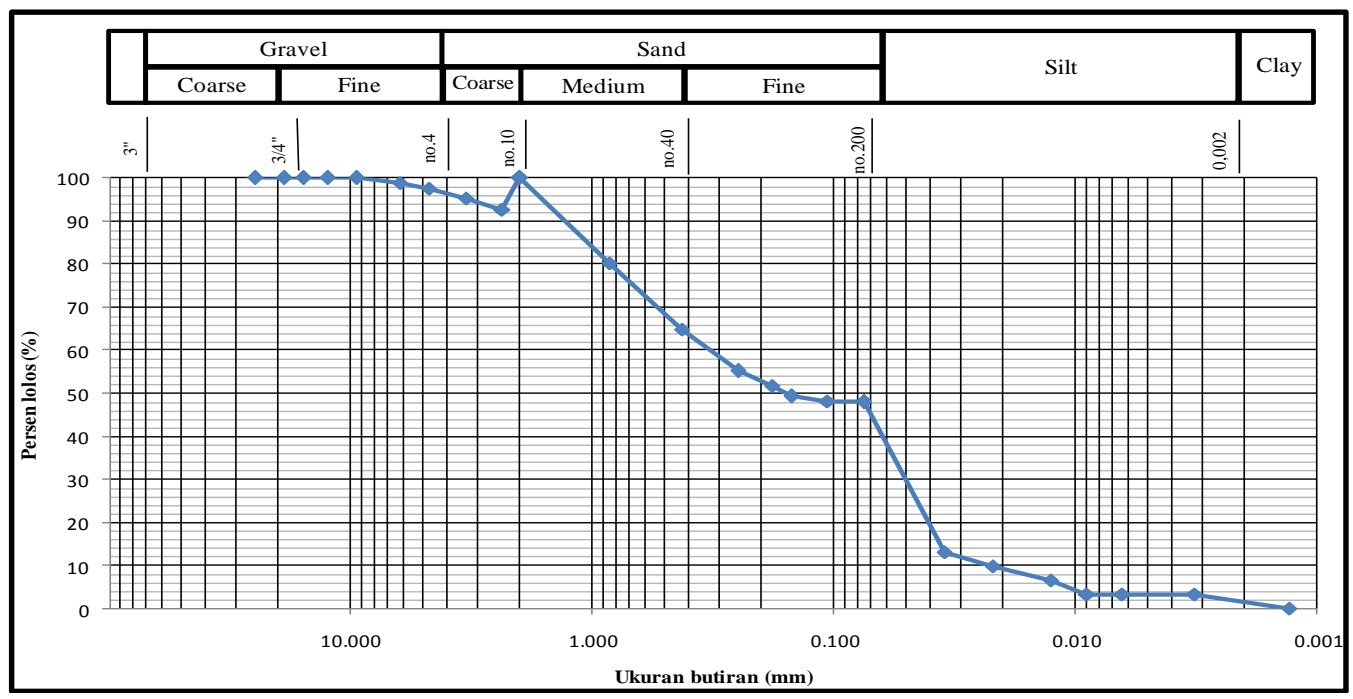

Gambar 6. Hasil Analisis Saringan Sampel Tanah

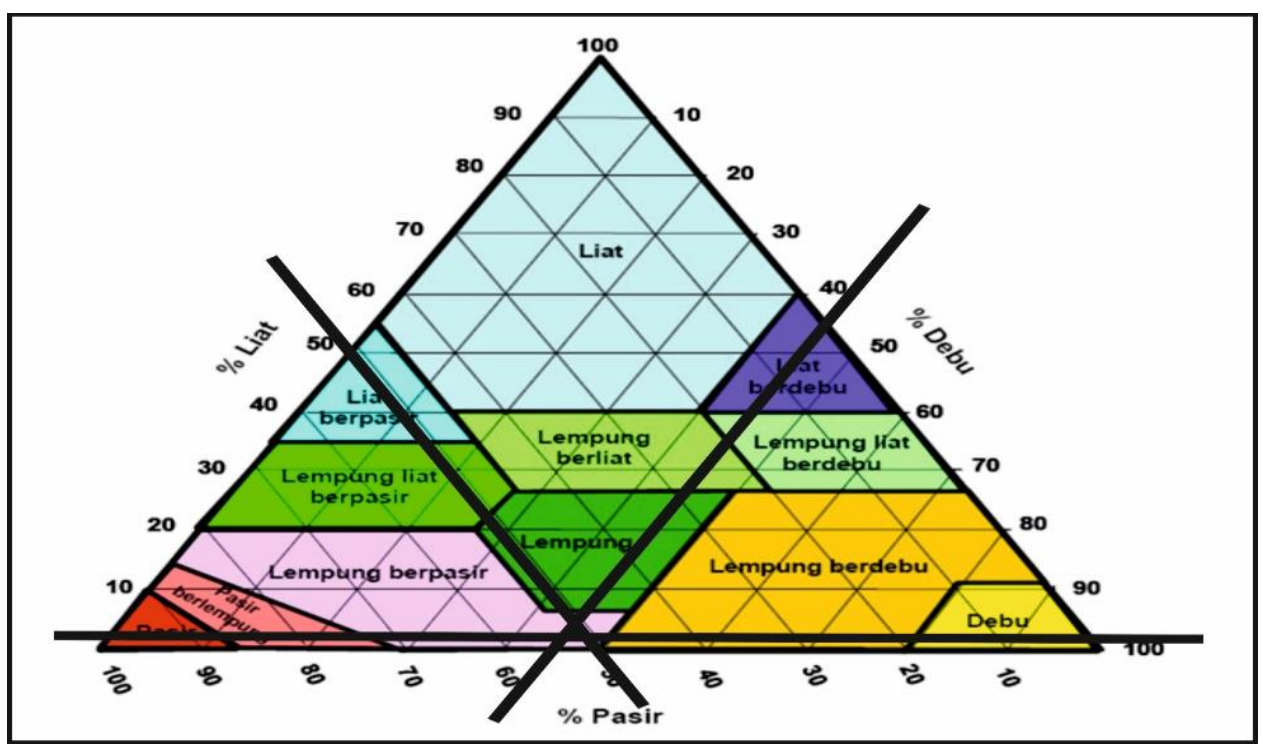

Gambar 7. Segitiga Tekstur Tanah

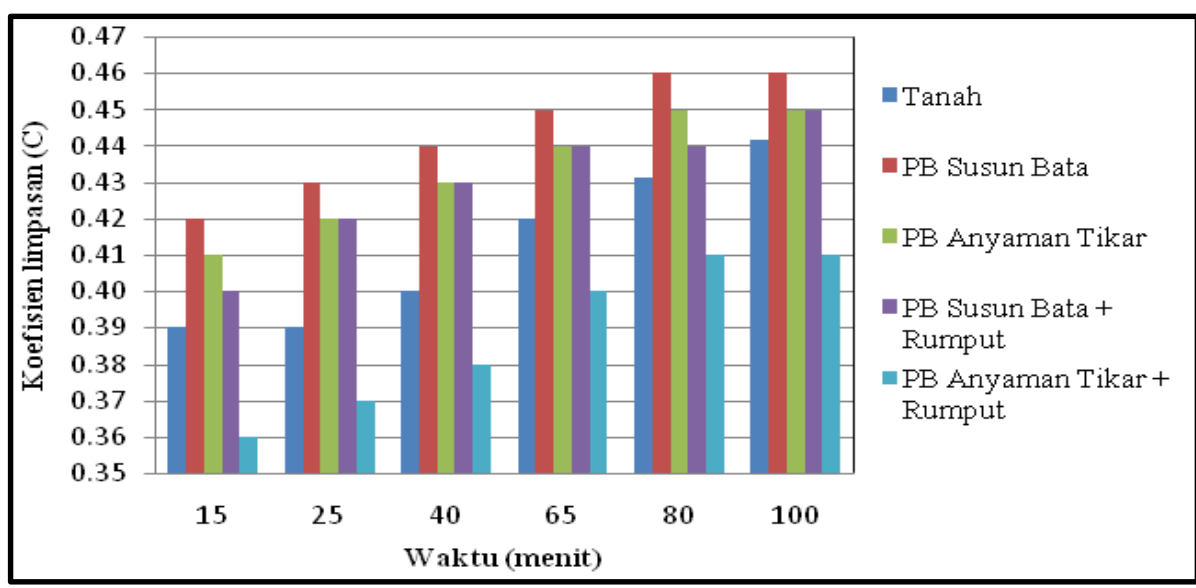

Gambar 8. Hubungan Koefisien Limpasan (C) dan Waktu pada masing-masing Tutupan Lahan 


\subsection{Volume Limpasan Permukaan}

Volume limpasan yang dihasilkan yaitu lahan tanah tanpa tutupan lahan volume terkecil 59 liter dan terbesarnya 441.5 liter, tutupan lahan paving block dengan pola pemasangan susun bata volume terkecil 62 liter dan terbesarnya 457 liter, kemudian paving block dengan pola anyaman tikar volume terkecil 60 liter dan terbesarnya 447 liter, paving block pola susun bata dengan penambahan rumput gajah mini volume terkecil 60 liter dan terbesarnya 444 liter, dan terakhir paving block pola anyaman tikar dengan penambahan rumput gajah mini volume terkecil 51.5 liter dan terbesarnya 405.5 liter.

\subsection{Koefisien Limpasan.}

Berdasarkan hasil analisis nilai koefisien limpasan (C) yang dihasilkan selanjutnya dibuat grafik hubungan antara variasi tutupan lahan, nilai koefisien (C), dan waktu pengujian (Gambar 8).

Dari Gambar 8 dapat dilihat nilai koefisien yang dihasilkan pada pengujian untuk semua variasi tutupan lahan. Untuk lahan tanah nilai koefisien limpasan (C) yang dihasilkan berkisar antara 0.39 0.44. Nilai koefisien limpasan (C) tertinggi yaitu tutupan lahan dengan paving block dengan pola pemasangan susun bata dengan nilai kofisien limpasan (C) berkisar antara $0.42-0.46$, sedangkan untuk tutupan lahan paving block dengan pola pemasangan anyman tikar memiliki nilai koefisien limpasan yang lebih kecil yaitu berkisar antara $0.41-0.44$.

Dengan adanya kombinasi antara pola pemasangan paving block dan rumput gajah mini memperkecil nilai koefisien limpasan. Nilai koefisien limpasan (C) untuk tutupan paving block pola susun bata dengan penambahan rumput nilai koefisien limpasan (C) berkisar antara $0.40-0.45$. Sedangkan untuk tutupan paving block dengan pola anyaman tikar nilai koefisien limpasan $(\mathrm{C})$ berkisar anatara $0.36-0.41$ dan merupakan tutupan lahan yang memiliki nilai koefiisien (C) terkecil dari semua variasi pengujian tutupan lahan, baik dengan lahan tanah, paving block tanpa rumput untuk kedua pola pemasangan paving block yaitu pola susun bata maupun anyaman tikar dan paving block pola susun bata dengan penambahan rumput gajah mini. Dari hasil koefisien limpasan (C) menunjukkan bahwa nilai koefisien aliran permukaan (C) terendah didapatkan dengan penggunaan penutup lahan paving block pola anyaman tikar dengan penambahan rumput gajah mini dan tutupan lahan paving block pola susun bata sebagai nilai tertinggi. 
Nilai koefisien aliran permukaan (C) semakin besar dengan tutupan lahan yang memiliki celah lebih sedikit. Karakteristik masing masing material penutup lahan yang digunakan berpengaruh terhadap nilai koefisien limpasan permukaan (C). Hasil penelitian didapatkan bahwa dengan mengkombinasikan pola pemasangan paving block dan penambahan penutup lahan vegetasi yaitu rumput gajah mini dengan memamfaatkan daerah spasi antar paving maka tercipta ruang - ruang sebagai tempat meresapnya air limpasan permukaan.

Selain itu dengan adanya penambahan rumput gajah mini berfungsi menghambat laju air limpasan permukaan, sehingga memberikan kesempatan pada tanah untuk meresapkan air limpasan permukaan. Hal ini dapat dikatakan bahwa dengan adanya penambahan tanaman rumput gajah mini pada spasi paving block dapat menambah daya resap air sehingga memperkecil nilai koefisien limpaasan permukaan $(\mathrm{C})$.
Tabel 5. Nilai Koefisien Limpasan Permukaan

\begin{tabular}{|c|c|c|}
\hline No. & $\begin{array}{l}\text { Diskripsi Permukaan } \\
\text { Lahan }\end{array}$ & Koefisien C \\
\hline 1 & $\begin{array}{l}\text { Tanah lempung } \\
\text { berpasir }\end{array}$ & $0.39-0.44$ \\
\hline 2 & $\begin{array}{l}\text { Paving block pola } \\
\text { susun bata }\end{array}$ & $0.42-0.46$ \\
\hline 3 & $\begin{array}{l}\text { Paving block pola } \\
\text { anyaman tikar }\end{array}$ & $0.41-0.44$ \\
\hline 4 & $\begin{array}{l}\text { Paving block pola } \\
\text { susun bata dengan } \\
\text { rumput gajah mini }\end{array}$ & $0.40-0.45$ \\
\hline 5 & $\begin{array}{l}\text { Paving block pola } \\
\text { anyaman tikar dengan } \\
\text { rumput gajah mini }\end{array}$ & $0.36-0.41$ \\
\hline
\end{tabular}

\section{SIMPULAN DAN SARAN}

\subsection{Simpulan}

Dari hasil penelitian dan pembahasan, maka dapat ditarik kesimpulan sebagai berikut:

1. Volume limpasan yang dihasilkan dari pengujian mengalami peningkatan besar volume limpasan tiap durasi waktu yang dipergunakan. Dengan volume limpasan yang dihasilkan yaitu lahan tanah tanpa tutupan lahan volume terkecil 59 liter dan terbesarnya 441.5 liter, tutupan lahan paving block dengan pola pemasangan susun bata volume terkecil 62 liter dan terbesarnya 457 liter, kemudian paving block dengan pola anyaman tikar volume 
terkecil 60 liter dan terbesarnya

447 liter, paving block pola susun bata dengan penambahan rumput gajah mini volume terkecil 60 liter dan terbesarnya 444 liter, dan terakhir paving block pola anyaman tikar dengan penambahan rumput gajah mini volume terkecil 51.5 liter dan terbesarnya 405.5 liter.

2. Adapun nilai koefisien limpasan yang didapatkan dengan variasi waktu $15,25,40,65,80$, dan 100 menit menunjukkan:

a. Lahan tanah nilai koefisien limpasan permukaan (C) yang dihasilkan berkisar $0.39-0.44$.

b. Penggunaan pekerasan paving block susun bata memiliki koefisien limpsan permukaan $(\mathrm{C})$ dengan nilai berkisar 0.42 - 0.46 .

c. Paving block anyam tikar nilai koefisien limpasan permukaan (C) yang dihasilkan berkisar 0.410.45 .

d. Paving block pola susun bata dengan penambahan rumput gajah mini Nilai koefisien limpasan permukaan (C) yang dihasilkan berkisar $0.40-0.45$.

e. Paving block pola anyaman tikar dengan penambahan rumput gajah mini. Nilai koefisien limpasan permukaan (C) yang dihasilkan berkisar 0.36 0.41 .

3. Dari hasil koefisien limpasan (C) menunjukkan bahwa nilai koefisien aliran permukaan (C) terendah didapatkan dengan penggunaan penutup lahan paving block pola anyaman tikar dengan penambahan rumput gajah mini dan tutupan lahan paving block pola susun bata sebagai nilai tertinggi. Hasil penelitian didapatkan bahwa dengan mengkombinasikan pola pemasangan paving block dan penambahan penutup lahan vegetasi yaitu rumput gajah mini dengan memamfaatkan daerah spasi antar paving maka tercipta ruang-ruang sebagai tempat meresapnya air limpasan permukaan, dan dengan adanya penambahan rumput gajah mini berfungsi menghambat laju air limpasan permukaan sehingga 
menambah daya resap air dan memperkecil nilai koefisien limpaasan permukaan (C).

\subsection{Saran}

Berdasarkan penelitian yang telah dilakukan dapat dibuat saran-saran yang bisa digunakan sebagai pertimbangan penelitian-penelitian selanjutnya:

1. Perlu adanya penambahan variasi perbandingan luas antara paving block dan rumput untuk melihat pengaruhnya terhadap nilai koefisien aliran permukaan (C).

2. Perlu dilakukan penelitian lanjutan dengan penambahan variasi jenis rumput dan kemiringan lahan.

\section{DAFTAR PUSTAKA}

Arfan, H., \& Pratama, A. (2012). Model Eksprerimen Pengaruh Kepadatan, Intensitas Curah Hujan dan Kemiringan Lahan terhadap Resapan pada Tanah Organik. Jurusan Teknik Sipil Fakultas Teknik Unhas.

Agus, F., Yusrial, \& Sutono. (18 Juli 2018). Penetapan Tekstur Tanah. $<$ http://balittanah.litbang.pertanian.g o.id>.

Akara, R., Sarino, \& Yuono, A.L. (2016). Pengaruh Intensitas Hujan dan Penutup Lahan (Land Cover) terhadap Nilai Koefisien Aliran Permukaan (C) Menggunakan
Rainfall Simulator. Cantilever, 5(1), 13-19.

Asdak, C. (2014). Hidrologi dan Pengelolaan Daerah Aliran Sungai. Gadjah Mada University Press: Yogyakarta.

Artiyani, A. (2010). Pemanfaatan Abu Pembakaran Sampah sebagai Bahan Alternatif Pembuatan Paving Block. Jurnal Spectra Institut Teknologi Nasional Malang, VIII(16), 1-11.

Arsyad, S., (2006). Konservasi Tanah dan Air. IPB Press: Bandung.

Castro, D., Angullo, G., Rodriuez, J., \& Calzada, M.A. (2007). The Influence of Paving-Block Shape on the Infiltration Capacity of Permeable Paving. Land Contamination \& Reclamation, 15 (3), 335-344.

Faisal, Z. (2008). Studi Limpasan Permukaan Pada Tanah Lempung Plastisitas Rendah Dengan Percobaan Laboratorium. Master Thesis, Program Studi Teknik Sipil Keairan Program Pascasarjana Universitas Hasanuddin Makassar.

Hanafiah, K.A. (2005). Dasar- Dasar Ilmu Tanah. Raja Grafindo Persada: Jakarta.

Harisuseno, D., Cahya, E.N., \& Puspasari, R.L. (2017). Studi Pengaruh Sifat Fisik Tanah Terhadap Karakteristik Laju Infiltrasi. Universitas Brawijaya.

Khairunnisa A.V., Yuwono, A.L., \& Sarino. (2017). Pengaruh Variasi Kemiringan dan Penutup Lahan (Land Cover) terhadap Debit Aliran Permukaan Menggunakan Rainfall Simulator. Cantilever, 6(1), 1-9.

Lapadjati, K. K., Wardah, \& Rahmawati. (2016). Sifat Fisik Tanah pada Hutan Tanaman Kemiri, Lahan Agroforestri 
dan Lahan Hutan Sekunder di Desa Labuan Kungguma Kabupaten Donggala Sulawesi Tengah. Jurnal Warta Rimba, 4(2).

Martono, (2004). Pengaruh Intensitas Hujan Dan Kemiringan Lereng Terhadap Laju Kehilangan Tanah Pada Tanah Regosol Kelabu. Master Thesis, Program Pascasarjana Universitas Diponegoro.

Nanda, A.R., \& Nurnawaty. (2015). Kapasitas Infiltrasi Tanah Timbunan dengan Tutupan Paving Blok. In Prosiding SNTT FGDT.

Sebayang, S., Diana, W., \& Purba, A. (2011). Perbandingan Mutu Paving Block Produksi Manual dengan Produksi Masinal. Rekayasa: Jurnal Ilmiah Fakultas Teknik Universitas Lampung, 15(2).

Sedyowati, L., Suhardjono, Suhartono, E., \& Sholichin, M. (2017). Runoff velocity behaviour on smooth pavement and paving blocks surfaces measured by a tilted plot. Journal of Water and Land Development, 33, 149-156.

Sedyowati, L., \& Susanti, E.I. (2017). Effect of Concrete Block Pavement on Flow Retardation Factor. Journal of Applied Engineering Science, 7(20), 28-36.

Saputro, C.I., Surendro, B. \& Amin, M. (2018). Pengaruh jenis permukaan terhadap besarnya limpasan air. Reviews in Civil Engineering, 2(2), 58-67.

Suripin. (2004). Sistem Drainase Perkotaan yang Berkelanjutan. Andi: Yogyakarta. 